\title{
Some Lithuanian ethnobotanical taxa: a linguistic view on Thorn Apple and related plants Daiva Šeškauskaitè ${ }^{\dagger 1}$ and Bernd Gliwa* ${ }^{* 2}$
}

\author{
Address: ${ }^{1}$ Kaunas College of Forestry and Environmental Engineering, Girionys, Lithuania and ${ }^{2}$ Sargeliai, Lithuania \\ Email: Daiva Šeškauskaitė - daivases@yahoo.de; Bernd Gliwa* - berndgliwa@yahoo.de \\ * Corresponding author †Equal contributors
}

Published: 02 March 2006

Journal of Ethnobiology and Ethnomedicine2006, 2:13 doi:10.1/86/1746-4269-2-13

This article is available from: http://www.ethnobiomed.com/content/2/1/13

(c) 2006Šeškauskaitė and Gliwa; licensee BioMed Central Ltd.

This is an Open Access article distributed under the terms of the Creative Commons Attribution License (http://creativecommons.org/licenses/by/2.0), which permits unrestricted use, distribution, and reproduction in any medium, provided the original work is properly cited.
Received: 17 January 2006

Accepted: 02 March 2006

\begin{abstract}
Background: The perception and use of plants correspond with common plant names. The study of plant names may give insight into historical and recent use of plants.

Methods: Plant names in dictionaries and folklore have been evaluated. A etymological analysis of the names is provided. Onomasiological and semasiological aspects have been considered. Therefore, species named with names related to each other have been selected.

Results: Plant names containing the stem dag- or deg- may belong to either of two categories: incenses or thorny plants. Plants named in durn- have been in use as psychopharmaca. The name rymo points not to Rome but to the use of plants as anodyne or psychopharmaca.
\end{abstract}

\section{Background}

The study of plant names is a quite old branche in ethnobotany. It is connected with comparative historical linguistics and Indo-European studies [1] or philological studies of singular languages, e.g. the dictionary of German plant names [2]. Names correspond with the perception and categorisation of plants. This is true for the binary scientific names [3] as well as for common plant names.

Linguistic studies have shown that plant names of common origin may refer to different plant species. E.g. Latin fägus 'Fagus sp.' vs. Old Greek phēgós 'Quercus sp.'. Various explanations have been given, the most frequent is probably the missing of a certain plant in the area where speakers of a language came to settle. Another view points to an open question: we do not know what the reconstructed Indo-European *bhago- really meant. It could name Fagus sp. as well as any tree with leaves or hard timber [4,5].

\section{Methods}

Lithuanian plant names have been selected from written sources and common use. A philological analysis of the names has been provided, their botanical meaning has been discussed. Both, semasiological and onomasiological aspects have been considered. Therefore, species with identical or similar names have been selected for the present study. The etymological analysis is related with plant names from neighbouring Slavic and Germanic languages. It is supposed that names correspond with the use of these plants in traditional medicine, rites and handicrafts. Ethnographic data about plants have been an important source for the study. Due to requirements of linguistic papers we italicise not only botanical taxa but also linguistic forms. We hope that this will not result in confusion. Diacritics have been omitted. 


\section{Results and discussion Durna}

Durnarope ist the most popular Lithuanian name for Datura stramonium. It is also used for recently introduced ornamental plants of the genus Brugmannsia. Other names for D. stramonium are durnadagilis, durnadagis, durnarejus, durnažolè, durniukas etc. [6,7]. Linguists compare these terms usually with Russian durman 'D. stramonium' and durnyj 'stupid' and claim that the Lithuanian plantnames and Lithuanian durnas 'stupid' have been borrowed from Slavic languages [8]. The origin of D. stramonium remains unclear until now. The species is indigenous either to Central America or to Asia or cosmopolitan. No sure evidence (palynolonogy, macro fossils) for neither views has been provided so far. It seems rather impossible to falsify one of these opinions. Therefore, linguistic discussion has no firm basis when it regards only this species. Additionally, there are other plants named in a similar way: durnažolé, durnius 'Hyoscyamus niger L.', durnažolè 'Atropa bella-donna L.', durnarepka 'Scopolia carniolica Jacq.' and durnažole 'Lolium temulentum L.' [6,9]. All species are psychoactive. No doubt, the names refer explicitly to this effort. Hyoscyamus niger and Lolium temulentum are indigenous plants or at least archeophyts.

The use of psychoactive plants is a human universality and-generally speaking-not a matter of loaning. If plant names in durn- were loans then there should be synonymous names with Lithuanian paikas, kvailas, žioplas, trenktas etc. 'stupid, crazy'. In fact, only a single žioplys 'idiot' appears for D. stramonium. Not only therefore, the conclusion is that durnas 'stupid' is not a loan but Baltic heritage, however, cognate with the Slavic words for narcotic plants, e.g. Russian durman, Belorussian durzilje 'D. stramonium', Russian durnišnik 'Xanthium L.', Ukrainian dur 'Hyoscyamus niger' [7].

A considerable number of Lithuanian phrases concern henbane, thorn apple etc. and their well known effort: "The drunkard gambols like having consumed henbane", "he talks nonsens as if he would have eaten thorn apple", "he turns around as if he would have consumed thorn apple" etc. [10]. The effort is temporary and primarily not a matter of character or intellect. Therefore, it is suggested that the original meaning of durnas etc. was not 'stupid' but 'drunken, high'. The use of psychoactive plants belongs to the responsibility of religion in quite a lot of cultures [11]. One can suppose that pre-Christian local religions used them as well. A hint is the name dievažolynis 'God's herb' for D. stramonium [10], where dievas 'God' is probably the Pagan god of heaven, predecessor of the Christian God, for the Catholic rite do not favour the use of narcotic plants.

\section{Rymo}

Several Lithuanian plant names contain the word Rymo: Rymo ridikas, Rymo ropikès 'Atropa bella-donna L. ', Rymo ropé 'Datura stramonium L.' and 'Scopolia carniolica Jacq. ', Rymo ramune 'Matricaria recutita L.' $[6,10]$. The spelling shows that Rymo has been understood as proper name: Rymo 'of Rome'-Old Lithuanian Rymas, Mod. Lith. Roma 'Rome'. Regarding origin, range and use of these plants one misses a clear motivation for this label [12]. Generally, ridikas refers to any tap-root, rope names turnip, tubers, knobsroots as well as fruits.

The origin of D. stramonium is not clear as mentioned above, but Rome is no serious option. For Scopolia carniolica the species designation carniolica refers to its origin respectively area of first description in Carniola. Russian belladonna occurs wild in the Carpathians, Caucasus, Alps [11]. Others note its spreading from the Apennine peninsula to East Europe [13] and a cultivation in Lithuania, Latvia and East Prussia and its use as narcotica, aphrodisiaca and for healing nervous fits [14]. However, $S$. carniolica has not even been mentioned by Dagys [6]. Atropa bella-donna grows wild in most parts of Europe, South East Asia and North Africa [13]. Matricaria recutita is an indigenous plant to Lithuania, now rather rare [15].

The species of the family Solanaceae under discussion have in common that they are introduced to Lithuania. That would it make possible to receive a geographic attribute as, to give an example, graikiškas riešutas 'Greek nut' Juglans regia $\mathrm{L}$. did. The latter agrees with the way the plant was cultivated and spread. The Persian Walnut is very often attributed with geographical terms [2]. On the contrary, the plants attributed in Rymo have no names in neighbouring languages referring to their origin, except Russian belladonna with a different localization, however. A recent study has shown that common Lithuanian plant names-not book names-refer very seldom to the geographic origin of the plant [16].

We suggest that rymo (genitive of rymas) has nothing in common with Rome. It is by accident phonetically equal to the Old Lithuanian name of Rome: Rymas. Therefore the option to reinterpret the meaning of the word-a folk etymology-has been given. But what is the origin of rymo? Have a look on data of Lithuanian lexicology and folklore.

A once popular Lithuanian game is named "ropę rauti" 'to root out the turnip' [17]. One actor explains that his wife has a violent urge for Rymo ridikas, therefore it should be rooted out right now [18]. Another version requires trimo lapo 'stanching leaf', because the actor has been bitten by a dog. 
The urge for Rymo ridikas appears in phrases such as Užsigeide kaip bobute Rymo ridiko 'She demands rymo turnip like an old woman' [17]. Noteworthy, in all versions of the phrases female persons require it. This circumstance makes it less convincing to argue with narcotica in this special case. The game is typical for wedding ceremonies, the man is looking for medicine for a female person. It could be supposed that the game was the modelling of birth and asking for the midwife. Therefore-asking the midwife-special phrases have been used, straightforward terms like child giving or birth were to avoided, usual encodings were e.g. pečius sugriuvo 'the stove tumbles down', gandras atneše broliuką 'the stork delivered a brother' [19].

Scopolia carniolica and Hyoscyamus niger are known for traditional use aborning to soothe the pain in labour $[9,20]$. D. stramonium and A. bella-donna are also anodynes. Data on real or possible use of the latter both species while child giving we did not observe. All plants in rymo are officinal ones. Lithuanian raminti 'to calm, quieten; soothe; console; ease pain' is a favourite word to express soothing. Related words are e.g. Lithuanian ryma 'tranquility, calm', rymoti 'to think, meditate', ramus 'quiet' $[8,10]$. There is no hindrance to integrate Rymo and all of the plant names into this word family.

Rymo ramune 'Matricaria recutita' is said to ease pain in the stomach: ramuliai vid y ramina [10]. Therefore, we suppose that not only rymo but also ramune belongs to the family of rimti 'to became quiet, calm' as well. Linguists claim that Lithuanian ramune etc. and others like Russian romaška 'Matricaria spp. etc.' goes back to Latin anthemis romana, chamaemelum romanum $[8,21]$.

However, the origin of this Latin name shows that it has nothing in common with Rome. Marzell [2] notes that romanum only means 'not native' here; but this is not the point. He remarks further that the claim mentioned by Mattioli in 1600 "the species grows around Timur near Rome" triggered off the use of romanum. In fact, it did not grow there at this time, it was unknown to authors of antiquity [2]. So, why did Mattioli claim this? The answer lies in this case in common German names, e.g. Romei, Remey 'Matricaria spp., Chamaemelum spp.' Relating the name which sounds like Rome to Rome is a usual linguistic process named folk etymology, the same as we report for Lithuanian Rymo.

The situation with the Russian material is very similar. Merkulova [21] notes Russian cvetu romanova 'Roman flower' and romanova trava 'Roman herb' found in written sources from 1534. She claims that Middle Age Latin called the plants anthemis romanum, chamaemelum roman, unfortunately without giving evidence for this claim. This would classify the names as pure book names. The Russian and Polish spelling of Rome is with $i$ or $y$. Versions with $o$ are quite new-from the $20^{\text {th }}$ century. So we have the strange situation that Russian rimskaja romaška 'Chamaemelum nobile' would point to Rome in both parts. The older one (romaška) would show the modern spelling of Rome. The new one, which is indeed a translation from a binary (Latin) plant name, shows the traditional spelling.

Therefore we conclude that Russian romaška as well as Lithuanian rymo, German Romei refers to the healing properties of Matricaria recutita. All these plant names should be cognate to each other. Similar plant names in rymo for Atropa bella-donna, Scopolia carniolica and Datura stramonium, on the one hand, and Matricaria recutita, on the other hand, result from the use of rimti for both, haemostatic effort on wounds (cf. German die Blutung einer Wunde stillen 'to staunch a wound' where still means 'calm, quiet') and the effort on the psyche.

\section{Dagys}

Lithuanian plant names containing the stem dag- or degmay belong to one of three different concepts. However, only one of them is taken into consideration usually i.e. the concept of thornes, spines and prickles: Lithuanian dagys and dagilis 'Carduus spp., Cirsium spp., Onopordum acanthium L., Silybum marianum Gaerth.', dagišius 'Xanthium spinosum L.', dyguldagis 'Datura stramonium L.' $[6,8,10]$. One more example, where dag- refers to the concept of thorns or the like are dagutis, diegiažolè, dygulis etc. 'Geum urbanum L.'. The plant has no thorns but the fruit is prickly like burdock's one. Lithuanian velniadagis 'diablo's prick' names Arctium sp.

The second concept refers to Lith. degti 'to burn' [22]. Deguèiukas 'Lychnis viscaria (L.) K. Jess' is related as well. This name, however, should be seen in relation to the use of stalks made from Lychnis spp. for candle wicks [2]. Lychnis had been derived from the Greek name for light as well [3].

A third concept has been introduced recently $[7,23]$. It is similar to the preceding one. It refers to a use as incense especially in healing.

Additionally, Lithuanian dagilis appears in refrains of of Lithuanian folk songs "Lio lelijela, lio dagilio; Lelijela, dagilio", "Dobile, dogile, Dobile, totata" [23]. Here, the term is connected with other plant names: lelija 'lily' and dobilas 'clover'. It is very difficult to find out which species is meant by dagilis. As we can exclude any reference to thorns, it seems possible to suggest a use as incense, e.g. for healing purposes. 
In order to heal the folk illness timorousness (Lithuanian išgastis) the patient is smoked with seeds of Datura stramonium L., flowers of Paeonia spp. and dagis [9], with dry grinded dagiliai [24]. The identity of the latter-dagis and dagiliai-remains unclear.

Different interpretations seem applicably for durnadagis, dyguldagis 'Datura stramonium'. It has been named thorn apple with respect to its thorny fruit. The use as incense has been attested: throwing $D$. stramonium on the hot sauna oven has been an erotically charged joke somewhere in rural Lithuania $[11,25]$. Common German plant names Rauchöffelkraut, Asthmakraut 'D. stramonium' [2] refers also to healing properties.

Common names of Potentilla erecta (L.) Raeusch. are beyond question. Degimai 'burning', degimo žole 'burning herb', degsnys 'burnt place' refer to words for burning; dagiai and dagiukas are suspected to do so as well. The plant was used as incense as can be seen from its name priemetžole 'herb for nervous fits'. The illness priemetis is widely healed smoking herbs.

\section{Conclusion}

Plants may-according to use and habit-belong to different ethnotaxa. This has been shown for three Lithuanian categories, each of them containing Datura stramonium. The affinity of a certain plant to a category is sensitive to the language used in the name-giving process-only a language where one word is appropriate for stanching wounds, easing pain and calming the psyche may group Atropa belladonna, Scopolia carniolica, Datura stramonium and Matricaria recutita together.

\section{Competing interests}

The author(s) declare that they have no competing interests.

\section{References}

I. Hehn V: Kulturpflanzen und Hausthiere in ihrem Übergang aus Asien nach Griechenland und Italien sowie in das übrige Europa. Historisch-linguistische Skizzen Berlin, Gebrüder Bornträger; 1870.

2. Marzell H: Wörterbuch der deutschen Pflanzennamen [reprint] Volume 5. Köln, Parkland; 2000.

3. Genaust H: Etymologisches Wörterbuch der botanischen Pflanzennamen Basel/Boston/Berlin, Birkhäuser; 1996.

4. Blažek V: The 'beech' argument - State-of-the-Art. Historische Sprachforschung 2002, I I 5(2): 190-217.

5. Binder VE: Wörter aus der Steinzeit - Völker aus dem Nichts. In Spektrum der Wissenschaft Dossier I; 2000:35-39.

6. Dagys J: Lietuviškas botanikos žodynas Kaunas, Spindulys; 1938.

7. Gliwa B: Die litauischen Namen des Weißen Stechapfels (Datura Stramonium L.). Res Balticae 2002, 8:93-106.

8. Fraenkel E: Litauisches etymologisches Wörterbuch Volume 2. Heidelberg/Göttingen, Winter/Vandenhoeck \& Ruprecht; 1962.

9. Kalašaitytė L: Liaudies medicinos priemonės. In Gervečai Edited by: Vèlius N. Vilnius, Mintis; 1989:204-219.

10. Ulvydas K, et al.: Lietuviu kalbos žodynas Volume 20. Vilnius; 1956.

II. Rätsch C: Enzyklopädie der psychoaktiven Pflanzen Aarau, AT Verlag; 1998.

12. Gliwa B: Stehen die litauischen Pflanzennamen Rymo ridikas, Rymo ropikès 'Atropa bella-donna', Rymo ropè 'Scopolia carniolica; Datura stramonium', Rymo ramunè 'Matricaria recutita' tatsächlich im Zusammenhang mit Rom? Baltu filologija 2004, I3(2): I3-32.

13. Zander R: Handwörterbuch der Pflanzennamen Stuttgart, Ulmer; 2000.

14. Abromeit J: Flora von Ost- und Westpreussen Volume I. Issue 2 Berlin; 1903.

15. Galinis V: Gentis Ramunè - Chamomilla. In Lietuvos TSR flora Volume 6. Edited by: Natkevičaitė-Ivanauskaitè M. Vilnius, Mokslas; 1980:97-100.

16. Genelytė A: Liaudišku fitonim y motyvacija (šiaurès panevěžiškiu ir kitu lietuviu kalbos tarmiu lyginimasis aspektas) (unpublished PhD thesis) Vilnius, LKI; 2004.

17. Grigas K: Smulkioji tautosaka žaidimai ir šokiai. Lietuvių tautosaka Volume 5. Vilnius, Vaga; 1968.

18. Valančius M: Raštai Volume I. Vilnius, LLTI; 200I.

19. Paukštytė R: Gimtuvès ir krištynos Lietuvos kaimo gyvenime Vilnius, Diemedis; 1999.

20. Pipinys J, Jaskonis J, Vaičiūnienè J: Vaistiniai augalai Vilnius; 1973.

21. Merkulova VA: Očerki po russkoj narodnoj nomenklature rastenij Moskva, Nauka; 1967.

22. Mažiulis V: Prūsų kalbos etimologijos žodynas Volume I. Vilnius, Mokslas; 1988.

23. Šeškauskaitè D: Sutartinès - senovés apeiginès giesmès Kaunas, Dakra; 2001.

24. Braziulienè V: Liaudies medicina Šiaulių rajone unpublished diploma thesis Vilnius, Vilnius University \& Institute of History; 1986.

25. Jasiūnaitè B: Skalsa beržo lapui! (Tradiciniai pirties linkèjimai). Kalbotyra 2000, 48-49(I):39-48.

\section{Publish with Biomed Central and every scientist can read your work free of charge}

"BioMed Central will be the most significant development for disseminating the results of biomedical research in our lifetime. " Sir Paul Nurse, Cancer Research UK

Your research papers will be:

- available free of charge to the entire biomedical community

- peer reviewed and published immediately upon acceptance

- cited in PubMed and archived on PubMed Central

- yours - you keep the copyright

Submit your manuscript here:

http://www.biomedcentral.com/info/publishing_adv.asp
Biomedcentral 